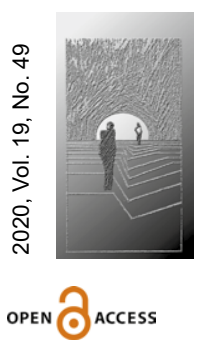

\title{
Edyta Zawadzka
}

http://orcid.org/0000-0001-6100-6607 Akademia Pedagogiki Specjalnej im. Marii Grzegorzewskiej Instytut Pedagogiki ezawadzka@aps.edu.pl DOI: $10.35765 / h w .1779$

\section{Edukacja rodzicielska oparta na programach śniadaniowych}

\section{STRESZCZENIE}

CEL NAUKOWY: Celem artykułu jest dokonanie analizy idei i treści przekazów pedagogizacyjnych obecnych w telewizji śniadaniowej, za kryterium przyjmując ich użyteczność jako źródła edukacji rodzicielskiej.

PROBLEM I METODY BADAWCZE: Problem badawczy wyraża się w pytaniu: jaka jest specyfika i jakość edukacji opartej na programach śniadaniowych? Prowadzone rozważania oparte są głównie na wynikach własnych badań, w których zastosowano metodę instrumentalnego studium indywidualnych przypadków i technikę analizy treści. Dla zarysowania kontekstu analizowanych zagadnień i potwierdzania formułowanych wniosków wykorzystano literaturę.

PROCES WYWODU: Charakterystyka edukacji rodzicielskiej konstruowana była poprzez podjęcie następujących zagadnień: przesłanki sytuujące się u podstaw uczestnictwa w procesie edukacyjnym, osoby pełniące w nich rolę ekspertów i rodzaje promowanych przez nich rodzajów wiedzy, okoliczności przebiegu nauczania i uczenia się oraz zagadnienia podejmowane w nich.

WYNIKI ANALIZY NAUKOWEJ: Pomimo holistyczności zagadnień o tematyce rodzicielskiej podejmowanych w programach śniadaniowych ich edukacyjna jakość i użyteczność, głównie z powodu różnych rodzajów wiedzy (naukowa, specjalistyczna, potoczna) znajdujących w nich odzwierciedlenie, cechują się niejednolitością i rozpatrywane muszą być indywidualnie dla każdego z nich.

WNIOSKI, INNOWACJE, REKOMENDACJE: Edukacja rodzicielska oparta na programach śniadaniowych ma ograniczony zakres i wymaga suplementacji, której istotnym założeniem jest uwzględnianie obok działań stricte pedagogizacyjnych również tych ukierunkowanych na przygotowywanie rodziców do funkcjonowania w społeczeństwie uczącym się.

$\rightarrow$ SŁOWA KLUCZOWE: EDUKACJA RODZICIELSKA, PEDAGOGIZACJA RODZICÓW, PROGRAMY ŚNIADANIOWE, PRZEKAZY O TEMATYCE RODZICIELSKIEJ OBECNE W PROGRAMACH ŚNIADANIOWYCH, TELEWIZJA ŚNIADANIOWA 


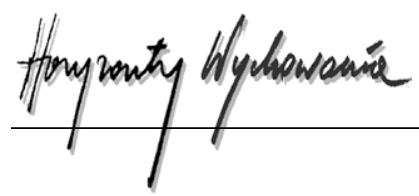

\section{ABSTRACT \\ Parenting Education Based on Breakfast Television Programs}

RESEARCH OBJECTIVE: The aim of the paper is to analyze idea and content of parenthoodrelated massages present in the breakfast programs in terms of their usability as a source of parenting education

THE RESEARCH PROBLEM AND METHODS: The research problem is expressed in the question concerning the specificity and quality of the education based on breakfast programs. The presented considerations are based mainly on the results of the author's own research, which utilized the method of instrumental study of individual cases and the content analysis technique. The literature was used to outline the context of the analysed issues and to confirm the formulated conclusions.

THE PROCESS OF ARGUMENTATION: The characterization of parenting education was developed by addressing the following issues: the rationale for participation in the educational process, the persons acting as experts in that process and the types knowledge they promote, the circumstances of the teaching and learning process, as well as the issues that are addressed in it.

RESEARCH RESULTS: Despite the holistic nature of parenthood-related issues discussed in the breakfast programs, their educational quality and usability are heterogeneous in character and must be considered individually for each of them, mainly due to the different types of knowledge (scientific, specialist, popular) which they reflect.

CONCLUSIONS, INNOVATIONS, AND RECOMMENDATIONS: Parenting education based on breakfast programs is limited in scope and requires supplementation, the essential objective of which is to include, in addition to the measures aimed strictly at pedagogization, also those aimed at preparing parents for functioning in the learning society.

$\rightarrow$ KEYWORDS: PARENTING EDUCATION, PARENTS PEDAGOGIZATION, BREAKFAST TELEVISION PROGRAMS, PARENTHOOD-RELATED MESSAGES DISCUSSED IN THE BREAKFAST PROGRAMS, BREAKFAST TELEVISION

\section{Wstęp}

Niezależnie od opisywanych w literaturze przedmiotu przekształceń w zakresie dzietności społeczeństwa (por. np. Błasiak, 2019; Kwak, 2005; Warzywoda-Kruszyńska i Krzyszkowski, 2004) dla wielu osób dorosłych pełnienie roli matki/ojca jest naturalnym elementem ich funkcjonowania, działalnością nadającą sens ich egzystencji, czynnikiem wpływającym na jakość życia, a także sposobem na spełnianie oczekiwań formułowanych wobec kobiet i mężczyzn (por. np. Bakiera, 2013; Hoghughi, 2004). Rola rodzicielska, szczególnie współcześnie, nie cechuje się homogenicznością, co uwarunkowane jest 
zarówno przypisaniem jej wielu zróżnicowanych ideowo zadań, jak i istnieniem licznych społecznie akceptowalnych wzorców jej realizacji (por. np. Bakiera, 2018; Błasiak, 2019; Dzwonkowska-Godula, 2015; Sikorska, 2009a; 2009b). Jest to jedna z podstawowych przesłanek uzasadniających tezę, że edukacja rodziców jest niezbędna i jawi się jako ważne wyzwanie współczesności (por. np. Skreczko, 2015; Śniegulska, 2016).

Funkcjonując w totalnie upedagogicznionym społeczeństwie, którego podstawową właściwością jest postrzeganie każdej dziedziny ludzkiego życia i efektywnego funkcjonowania w niej w perspektywie kompetencji, które jednostka powinna posiadać, wytrenować lub permanentnie aktualizować (por. Bernstein, 2010), rodzice czują się zobowiązani do podejmowania działań ukierunkowanych na nabywanie kompetencji optymalizujących realizację pełnionej roli i korzystanie w tym procesie z różnych źródeł - również, a właściwie zwłaszcza tych znajdujących się poza systemem formalnej edukacji, np. mediów, które ze względu na swoją wszechobecność (por. Goban-Klas, 2009) oferują niemal nieograniczony dostęp do wielu zróżnicowanych informacji. Jednym z rodzajów audycji obecnych w nich są programy śniadaniowe; rodzice pozostający na urlopach rodzicielskich lub przygotowujący siebie i swoje dzieci do wyjścia z domu i rozpoczęcia dnia w pracy i przedszkolu/szkole stanowią ich grupę odbiorców (por. Forma, 2014). Są one, jak zauważa O. Dąbrowska-Cendrowska (2011), definiowane przez wskazanie trzech ich głównych cech odnoszących się kolejno do: pory emisji (ranek i wczesne popołudnie), obecności w nich informacji dotyczących różnych dziedzin i sfer życia człowieka oraz ich głównie rozrywkowej funkcji. Niezależnie jednak od ich ludyczno-rekreacyjnej funkcji, dzięki dostępności i mnogości pojawiających się w nich informacji mających charakter porad (por. Dąbrowska-Cendrowska, 2013), wydaje się, że przynajmniej część rodziców postrzega je jako ważne źródło informacji. Podejmowanie rozważań nad ich edukacyjnym potencjałem jest zatem istotne zarówno z punktu widzenia teoretycznych rozważań prowadzonych na gruncie nauk społecznych ${ }^{1}$ i dotyczących współczesnych kontekstów całożyciowego uczenia się, jak i praktycznego wspierania rodziny w realizacji przypisanych jej funkcji. Celem artykułu jest zatem dokonanie analizy idei i treści przekazów pedagogizacyjnych obecnych w telewizji śniadaniowej, za kryterium przyjmując ich użyteczność jako źródła edukacji rodzicielskiej.

\section{Metoda i techniki badawcze}

Rozwiązanie postawionego problemu badawczego wymagało konceptualizacji i realizacji badań empirycznych. Były one prowadzone metodą instrumentalnego studium indywidualnych przypadków, której użycie, zdaniem R. Stake'a (2010), zasadne jest wtedy, gdy

${ }^{1}$ Kwerenda polskiej literatury przedmiotu pozwala na sformułowanie wniosku, że pomimo obecności pozycji podejmujących tematykę programów śniadaniowych (por. np. Dąbrowska-Cendrowska, 2013; 2014; Jankowska-Bulla, 2014; Sanakiewicz, 2013) ich pedagogiczne znaczenie ujmowane w kontekście edukacji rodzicielskiej jest w nich kwestią zupełnie pomijaną lub sygnalizowaną w momencie omawiania pojawiających się w nich materiałów o charakterze psychologicznym. 


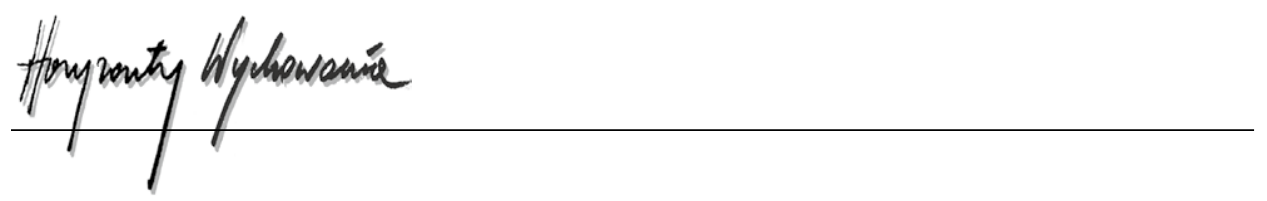

wnioski z analizy konkretnego przypadku/ów mają służyć pogłębieniu wiedzy na temat szerzej rozumianego zjawiska lub sformułowaniu konstatacji o wyższym stopniu ogólności. W ramach tej metody zastosowano analizę treści (por. Rapley, 2010).

Z uwagi na fakt, że w polskiej telewizji obecne są dwa programy śniadaniowe - Dzień Dobry TVN oraz Pytanie na Śniadanie, przedmiotem analizy uczyniono obecne w nich przekazy dotyczące tematyki związanej z szeroko ujmowanym rodzicielstwem i wychowywaniem dzieci. Dobór próby badawczej postanowiono ograniczyć do tych, które prezentowane były w ww. audycjach od lipca do października 2019 r. ${ }^{2}$ Uznano bowiem, że okres czterech miesięcy, w którym zawierają się zarówno miesiące wakacyjne, jak i „zwykłe”, stwarza właściwą płaszczyznę dla pozyskania danych, które uznać można za kompleksowe. Łącznie do próby włączono 64 programy śniadaniowe, z czego 30 były to programy emitowane od poniedziałku do piątku ${ }^{3}$, a 34 weekendowe $^{4}$. Z programów tych, dążąc do maksymalnego tematycznego zróżnicowania i teoretycznego nasycenia próby, wybrano 60 pojedynczych rozmów (po 30 będących reprezentantami każdego z programów) dotyczących ww. tematyki, które poddano pogłębionej analizie, co możliwe było poprzez powtórne ich obejrzenie na stronach internetowych programów.

Operacjonalizując postawione pytanie badawcze, stworzono narzędzie badawcze, które zawierało katalog zagadnień konkretyzujących i ukierunkowujących zakres prowadzonych analiz.

Konstruując wywód, posłużono się również literaturą przedmiotu, w której poszukiwano zagadnień stwarzających kontekst dla analizowanych kwestii, jak i weryfikujących formułowane wnioski.

\section{Charakterystyka edukacji rodzicielskiej bazującej na przekazach obecnych w programach śniadaniowych}

Opisując specyfikę i jakość edukacji rodzicielskiej będącej przykładem fali pedagogizacji nazywanej niedyrektywną i rozproszoną (por. Marynowicz-Hetka, 2013), postanowiono zastosować perspektywę integralną. Wyraża się ona w omawianiu w kolejnych akapitach zidentyfikowanych cech programów śniadaniowych oraz bazującej na nich edukacji, co zdaniem autorki wpływa na klarowność konstruowanej charakterystyki.

\footnotetext{
${ }^{2}$ W tym okresie program Pytanie na Śniadanie emitowany był codziennie. Dzień Dobry TVN od 1 lipca do 11 sierpnia widzowie mogli oglądać w weekendy, a od 12 sierpnia w każdy dzień tygodnia.

${ }^{3}$ Liczba 30 jest wynikiem przyjętego sposobu doboru próby badawczej. W okresie codziennej emisji programów, losowano nazwy dwóch roboczych dni tygodnia, a następnie nazwę programu. W okresie od 1 lipca do 11 sierpnia, z uwagi na fakt, że Telewizja TVN zrezygnowała z wydań codziennych, oglądano jedno wydanie Pytania na Śniadanie.

${ }^{4}$ Liczba 34 jest wynikiem przyjętego sposobu doboru próby. Z uwagi na fakt, że w sobotę i niedzielę, w okresie od lipca do października, emitowane były oba programy, postanowiono do próby włączyć wszystkie weekendy (17), a losowaniem objąć programy emitowane w poszczególne dni.
} 
Zagadnieniem wprowadzającym są przesłanki sytuujące się u podstaw uczestnictwa w tytułowym procesie edukacyjnym. Ze względu na przyjęty model badań niezakładający badania opinii rodziców jego omówienie oparte jest na refleksjach autorki. Partycypacja w tak ukonstytuowanej edukacji rozpatrywana może być w dwóch perspektywach. Pierwsza z nich wiąże się ze świadomą decyzją podmiotu i wymaga od rodziców przejawiania postawy aktywnej wyrażającej się w wyborze spośród wielu dostępnych źródeł tych, które odpowiadają w największym stopniu ich preferencjom i potrzebom edukacyjnym, co wydaje się zgodne z (postulowanymi) cechami edukacji dorosłych (por. np. Solarczyk-Szwec, 2010) oraz dodatnio wpływa na przejawianą w tym procesie refleksyjność. Jednocześnie jednak implikacją powszechnej obecności przekazów o tematyce rodzicielskiej w programach śniadaniowych ${ }^{5}$ jest stwarzanie rodzicom moźliwości zapoznawania się z nimi w trakcie podejmowania aktywności ukierunkowanych na cele inne niż edukacyjne, np. związane z organizacją czasu czy rozrywką. W takiej sytuacji ich odbiór wydaje się naturalny, niepoddawany głębszym przemyśleniom oraz rzadziej konfrontowany z posiadanymi potocznymi teoriami pedagogicznymi, a sama edukacja dokonuje się, posługując się terminologią używaną przez E. Dubas (2010), przez przypadek.

Kolejny komponent konstruowanej charakterystyki to osoby pełniące rolę ekspertów w analizowanych audycjach. Działania pedagogizacyjne w szkole na ogół realizowane są przez osoby posiadające przygotowanie pedagogiczne i/lub psychologiczne (por. Marynowicz-Hetka, 2013), a zatem przekazywane informacje powinny być zgodne z wiedzą naukową lub profesjonalną. Przekazy obecne w programach śniadaniowych cechują się wyższym zróżnicowaniem w tym zakresie. Możliwe jest bowiem zidentyfikowanie zarówno takich, w których uczestnikiem rozmowy prowadzonej przez gospodarzy programów jest osoba legitymująca się stopniem/tytułowym naukowym, posiadająca przygotowanie lub wykonująca zawód (np. dietetyka, psychologa, pedagoga, socjologa, lekarza, nauczyciela, terapeuty, trenera umiejętności wychowawczych, instruktora, ekonomisty, architekta), co stanowi uzasadnienie postrzegania jej jako autorytetu w danej dziedzinie (w 24 spośród 60 rozmów występowała taka sytuacja), jak i takich, gdzie za eksperta uznawany jest posiadający dzieci, własne doświadczenia wychowawcze i osobistą wiedzę potoczną rodzic czy inny członek rodziny ${ }^{6}$ (5 przypadków) lub dziecko (1 przypadek) ${ }^{7}$.

${ }^{5}$ Analiza obejrzanych programów śniadaniowych pozwala na sformułowanie wniosku, że w każdym wydaniu obecna była minimum jedna rozmowa dotycząca stricte zagadnień związanych z rodzicielstwem i wychowaniem. Ponadto problematyka ta podejmowana była pośrednio również $w$ trakcie rozmów na inne tematy.

${ }^{6}$ Rolę eksperta rodzic pełnił np. w przypadku tematu dotyczącego błędów popełnianych w trakcie wychowania pierwszego dziecka i różnic pomiędzy wychowywaniem jego i kolejnych dzieci (PnŚ, 17.07.2019), macierzyńskiej frustracji w dążeniu do ideału i jej konsekwencjach (PnŚ, 18.08.2019), kosztów i składu „wyprawki szkolnej” (DDTVN, 30.08.2019),

${ }^{7}$ W jednym z przekazów obecnych w programie Dzień Dobry TVN (20.08.2019) uczennica rozpoczynająca II klasę szkoły podstawowej opowiadała o swoich szkolnych doświadczeniach związanych z początkiem edukacji na I etapie edukacyjnym oraz poproszona została o udzielenie rady dzieciom rozpoczynającym szkolną edukację. Ponadto w rozmowach, w których brali udział 


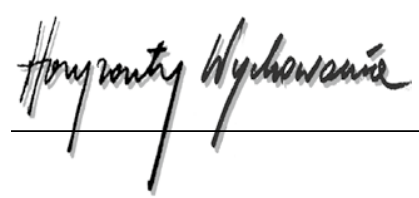

Ponadto w programach śniadaniowych szczególnie często (30 przypadków) dostrzegalna jest sytuacja zapraszania eksperta oraz rodzica ${ }^{8}$ jako osób reprezentujących rodzaje wiedzy znajdujące się na krańcach kontinuum i konfrontowanie ich poglądów. Oczywiście symplifikacją byłoby stwierdzenie, że niespecjalista nigdy nie ma racji, wręcz przeciwnie, wiedza ta może być użyteczna, jednak bywa fragmentaryczna, silnie nasycona subiektywizmem i uwarunkowana osobistymi doświadczeniami (por. np. Śliwerski, 2003).

Pełnienie w programach śniadaniowych roli ekspertów przez rodziców wydaje się egzemplifikacją sytuowania tej grupy wewnątrz procesów nieformalnej edukacji. Inne przykłady to zachęcanie oglądających do wyrażania swojej dychotomicznie ujmowanej opinii (tak/nie) w przeprowadzanych w trakcie audycji sondach ${ }^{9}$. Widzowie mają również okazję wyrażać swoje zdanie w formie komentarzy do umieszczanych na stronie internetowej materiałów (DDTVN ${ }^{10}$ ) oraz na profilach programów w portalu społecznościowym ${ }^{11}$, a także udostępniać materiały na Facebooku i Twitterze. Dzięki temu oglądający może nie tylko czuć się odbiorcą przekazów, ale również mieć wrażenie czynnego uczestnictwa (por. Sanakiewicz, 2013).

Opisane powyżej strategie związane z tworzeniem rodzicom płaszczyzny do interaktywności są jedną z cech opisujących okoliczności, w których przebiega nauczanie i uczenie się. Uzupełniając tę charakterystykę, zaakcentować należy również, że proces ten odbywa się w przyjaznej, koncyliacyjnej atmosferze, w której (przynajmniej wprost) ani rozmówcy, ani widzowi nie jest narzucane jednoznaczne podejście wobec dyskutowanych kwestii ${ }^{12}$.

dorośli, uczestniczyła również niekiedy młodzież dzieląca się swoimi opiniami i doświadczeniami (DDTVN, 20.07.2019; PnŚ, 28.07.2019, 14.10.2019).

${ }^{8}$ Rodzice i specjaliści brali np. udział w rozmowach dt. późnego ojcostwa (DDTVN, 04.09.2019), edukowania dzieci w kwestii ekologii (DDTVN, 13.08.2020), rozmawiania z dziećmi o ich ciele i nazwach narządów płciowych (PnŚ, 01.07.2019), komunikacji z noworodkiem (PnŚ, 19.09.2019).

${ }^{9} \mathrm{~W}$ analizowanym okresie widzowie mieli np. okazję wyrazić swoją opinię, odpowiadając na następujące pytania związane $z$ tematyką rodzicielską: „Czy dzieci powinny pracować?” (DDTVN, 03.10.2019), „Czy dziecko powinno mieć rodzeństwo?” (DDTVN, 17.10.2019).

${ }^{10}$ Redakcje obu programów umieszczają materiały na stronie internetowej, jednak Dzień Dobry TVN stwarza możliwości do ich komentowania w tym miejscu. Pytanie na Śniadanie umożliwia natomiast przesłanie wiadomości e-mail.

${ }^{11} \mathrm{~W}$ tym kontekście należy zauważyć, że niemal wszystkie (w badanej próbie 26 spośród 30) materiały z PnŚ zostały umieszczone w postaci linku na portalu społecznościowym, w przypadku DDTVN było to 12 rozmów. Analiza komentarzy umieszczanych na stronie internetowej DDTVN wskazuje, że ta forma nie budzi zainteresowania widzów - większość materiałów (28 spośród 30) nie została w ogóle skomentowana, pozostałe dwa dotyczące odpowiednio początku roku szkolnego i wydatków z nim związanych (30.08.2020) oraz pasożytów dziecięcych skomentowane zostały raz. Skłonność widzów do komentowania materiałów linkowanych na Facebooku jest zróżnicowana i waha się od 0 do 281 i średniej 78,83 (DDTVN) oraz od 4 do 550 i średniej 107 (PnŚ).

${ }^{12}$ Przyjęcie takiego podejścia, pomimo stanowiącego o jego potencjale uwzględnianiu podmiotowości gości programu oraz widza, zwłaszcza w sytuacji uczestnictwa w rozmowie specjalisty i rodzica jako ekspertów, wydaje się stawiać rodzica przed wyzwaniem wyboru pewnych treści jako 
Jednocześnie prowadzący pełnią rolę rzeczników widzów, zadając pytania i rozwiewając wątpliwości, które mogłyby się potencjalnie pojawić u oglądających, ale również precyzując kryteria doboru porad (np. skuteczność - PnŚ, 24.07.2019, rozmowa dotycząca usypiania dzieci). Ponadto zapewne ze względu na szerokie i zróżnicowane grono odbiorców w programach śniadaniowych wiedza przekazywana jest w formie powszechnie zrozumiałej oraz w stosunkowo krótkim czasie (średni czas trwania rozmowy w analizowanej próbie badawczej to 7,64 minut), co prowadzić może do infantylizacji czy upraszczania informacji, zwłaszcza tych zakorzenionych w wiedzy naukowej czy profesjonalnej.

Z punktu widzenia znaczenia programów śniadaniowych jako jednego ze źródeł budowania kultury pedagogicznej rodziców bardzo ważna jest tematyka obecnych w nich przekazów. Ujmując ją holistycznie, zasadne jest sformułowanie wniosku, że cechuje się ona hybrydowością i znacznie wykracza poza zagadnienia łączone tradycyjnie z pedagogizacją rodziców, np. funkcje rodziny, cele, zadania, treści, uwarunkowania, uczestnicy wychowania i relacje między nimi (por. Kawula, 1997). Odzwierciedlenie znajduje w niej szeroka koncepcja wychowania, uwzględniająca różne potrzeby i sfery rozwoju dziecka oraz związki pomiędzy nimi ${ }^{13}$. Oglądając programy śniadaniowe, rodzice mogą pozyskać również informacje lub rady odnoszące się do praktycznych aspektów realizacji roli rodzicielskiej, codziennych problemów czy dylematów wychowawczych ${ }^{14}$, profilaktyki zagrożeń współczesności ${ }^{15}$, zapoznać się z alternatywnymi metodami wychowania i kształcenia ${ }^{16}$ czy pozyskać inspirację do pewnych przekształceń w realizowanej działalności

tych mogących potencjalnie znaleźć zastosowanie w realizowanej działalności rodzicielskiej, przy jednoczesnym braku posiadania kryteriów pozwalających na ocenę ich jakości.

${ }^{13} \mathrm{~W}$ analizowanym okresie w programach śniadaniowych prowadzono rozmowy na m.in. następujące tematy: stosowanych przez dzieci mistyfikacji jako sposobu zwracania na siebie uwagi rodziców (PnŚ, 12.07.2019), psychodermatologii (PnŚ, 03.08.2019), edukowania potomstwa w kwestiach ekologii (DDTVN, 13.08.2019), stosowania diety bezmięsnej w przypadku małych dzieci (PnŚ, 05.08.2019), stymulowania dziecięcego mózgu (PnŚ, 10.09.2019), zajęć na basenie dla niemowląt (DDTVN, 26.09.2019), wspólnego czytania (DDTVN, 26.09.2019), nadpobudliwości u dzieci (DDTVN, 12.09.2019), pracy zarobkowej dzieci (DDTVN, 4.10.2019), uczenia programowania (PnŚ, 14.10.2019), co potwierdza tę tezę.

${ }^{14} \mathrm{~W}$ analizowanym okresie, oglądając programy śniadaniowe, rodzice mieli okazję zapoznać się m.in. z przekazami dt. informowania dziecka o nowym partnerze rozwiedzionego rodzica (PnŚ, 21.07.2019), sposobów postępowania w sytuacji niechęci dziecka do uczęszczania do przedszkola (Pnś, 29.08.2019), czynienia domu bezpiecznym dla dziecka (DDTVN, 4.09.2019), właściwego reagowania rodziców na słowo „zaraz" jako sposobu odkładania obowiązków na później przez nastolatków (DDTVN, 03.09.2019), złego dotyku i strategii rozmawiania z potomstwem na ten temat (PnŚ, 18.09.2019), wyzwań pojawiających się w pierwszym roku życia dziecka (DDTVN, 25.10.2019)

${ }^{15} \mathrm{Cel}$ ten realizowała rozmowa dt. narkotyków jako wakacyjnego zagrożenia (DDTVN, 16.08.2019).

16 Jako przykład możliwe jest wskazanie tematu wychowania przez wzmacnianie (DDTVN, 27.09.2019) czy wykorzystanie zabawy i alternatywnych metod w nauczaniu języka angielskiego (Pnś, 05.08.2019). Jednocześnie poza analizowanym okresem w programie DDTVN rozmawiano na temat edukacji domowej. 


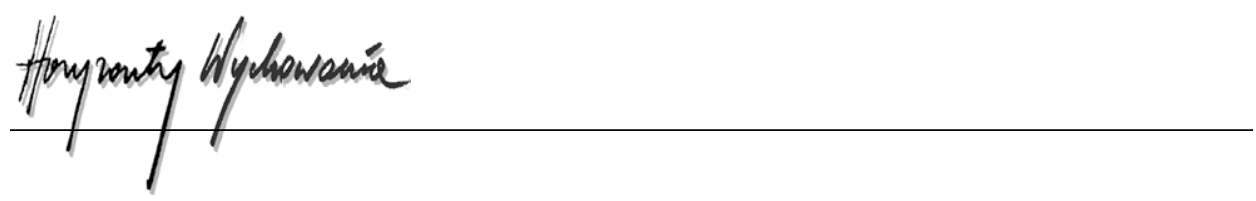

wychowawczej ${ }^{17}$. W analizowanych audycjach chętnie podejmuje się również tematy związane z bieżącymi wydarzeniami stającymi się udziałem rodziców i dzieci (np. rekrutacja do szkół ponadpodstawowych/ponadgimnazjalnych - DDTVN, 20.07.2019, szkolne wydatki - PnŚ, 03.08.2019, „cyrografy” obejmujące szkolne nakazy i zakazy, które mają podpisywać dzieci - PnŚ, 22.09.2019, Halloween - DDTVN, 31.10.2019). W tym kontekście jednak należy, powołując się na M. Sanakiewicza (2013), zauważyć, że podejmowane kwestie nie są omawiane w sposób pogłębiony, a jedynie sygnalizowane. Co więcej, w ramach edukacji realizującej się dzięki programom śniadaniowym rodzic nie otrzyma instruktaży czy rad, jak krok po kroku rozwiązać problem czy ustosunkować się wobec jakiegoś wyzwania wychowawczego, a raczej zachęcony zostanie (intencjonalnie lub nie) do dalszych poszukiwań.

\section{Zakończenie}

Ogólnodostępność i wieloaspektowość kwestii podejmowanych w programach śniadaniowych oraz ich adekwatność do potrzeb rodziców wydaje się stwarzać im sposobność do podejmowania aktywności zmierzających do budowania i rozwijania kompetencji rodzicielskich, szczególnie ich komponentu odnoszącego się do wiedzy i postaw, w mniejszym stopniu do umiejętności. Ich ocena obok kryterium tematyki uwzględniać musi jednak również to jakościowe nierozerwalnie powiązane z formą przekazu warunkowaną zróżnicowanym gronem odbiorców i specyfiką tego rodzaju programów, ich ukierunkowaniem na inne obok edukacyjnych cele, a także ich oparciem na różnych rodzajach wiedzy i związanymi z tym potencjałem i zagrożeniami. Skonstruowana w tekście charakterystyka skłania do sformułowania wniosku, że ich edukacyjna jakość i użyteczność cechuje się zatem niejednolitością i rozpatrywana musi być indywidualnie dla każdego z przekazów. W konsekwencji edukacja rodzicielska oparta na programach śniadaniowych ma ograniczony zakres i wymaga suplementacji. Przekazy dostępne w programach śniadaniowych powinny być przez matki i ojców postrzegane zatem nie jako źródło zapewniających sukces wychowawczy rad czy rozwiązań, ale raczej jako czynniki poszerzające świadomość rodzicielską i stanowiące asumpt do podjęcia osobistej refleksji i dalszych poszukiwań w innych źródłach, a także ich dostosowania do sytuacji będącej udziałem dziecka i rodziny.

Powyższa konstatacja stanowi punkt wyjścia do sformułowania rekomendacji dla instytucji, które z założenia mają wspierać rodzinę w realizacji funkcji wychowawczej i opierać swoją działalność na wiedzy naukowej i profesjonalnej. Wspomagając rodziców w budowaniu ich kultury pedagogicznej, zatrudnione w nich osoby powinny być nie tylko otwarte na potrzeby poznawcze matek i ojców, przekazywać im informacje w sprzyjającej recepcji formie, ale przede wszystkim uwzględniać w swoich działaniach

${ }^{17}$ Przykładem jest rozmowa, która odbyła się w Pytaniu na Śniadanie 15.08.2019, zatytułowana „Jak nauczyć dzieci dyscypliny bez klapsów i krzyku?”. 
przygotowywanie rodziców do funkcjonowania w społeczeństwie uczącym się, które polega na budowaniu postaw racjonalnych i krytycznych wobec informacji dostarczanych przez kulturę popularną.

W tekście zrezygnowano z formułowania rekomendacji dla twórców programów śniadaniowych, uznając je za utopijne, bowiem dostrzeżone ich niedoskonałości oraz ograniczenia w zakresie bycia źródłem edukacji rodzicielskiej wynikają z ich specyfiki jako gatunku telewizyjnego opartego na innych niż edukacyjne założeniach.

\section{BIBLIOGRAFIA}

Bakiera, L. (2013). Zaangażowane rodzicielstwo a autokreacyjny aspekt rozwoju dorosłych. Warszawa: Difin.

Bakiera, L. (2018). Styl realizacji rodzicielstwa a społeczny kontekst funkcjonowania współczesnych rodziców. W: B. Harwas-Napierała i L. Bakiera (red.), Oblicza współczesnej rodziny. Poznań: Wydawnictwo UAM, 31-66.

Bernstein, B. (2010). From Pedagogies to Knowledges. W: A. Morais, I. Neves, B. Davies i H. Daniels (red.), Towards a Sociology of Pedagogy: The Contribution of Basil Bernstein to Research. Nowy Jork: Peter Lang, 363-368.

Błasiak, A. (2019). Tendencje zmian we współczesnych rodzinach w ponowoczesności. Horyzonty Wychowania, 18(45), 11-21. DOI: 10.17399/HW.2019.184501. https://horyzonty.ignatianum. edu.pl/HW/article/view/1710

Dąbrowska-Cendrowska, O. (2011). Telewizja śniadaniowa. Celebryci, porady i audiotele - przynęty na kobiecą publiczność. Media i Społeczeństwo, 1, 29-39.

Dąbrowska-Cendrowska, O. (2013). Rozmawianie na ekranie - polska telewizja śniadaniowa w roli porannego towarzysza. Zeszyty Prasoznawcze, T. 56, 4(216), 477-494. DOI: 10.4467/22996362PZ.13.025.1544. www.ejournals.eu/Zeszyty-Prasoznawcze/

Dąbrowska-Cendrowska, O. (2014). Poranny towarzysz i doradca. Polskie telewizje śniadaniowe na przykładzie programów Dzień Dobry TVN i Pytanie na Śniadanie. Warszawa: Dom Wydawniczy Elipsa.

Dubas, E. (2010). Uczenie się przez przypadek jako przestrzeń edukacji dorosłych. Perspektywa biograficzna. W: A. Fabiś i A. Stopińska-Pająk (red.), Uczący się dorosły w zmieniającym się świecie. Bielsko-Biała: Wyższa Szkoła Administracji, 81-98.

Dzwonkowska-Godula, K. (2015). Tradycyjnie czy nowocześnie. Wzory macierzyństwa i ojcostwa w Polsce. Łódź: Wydawnictwo Uniwersytetu Łódzkiego.

Dzień Dobry TVN (2019). Telewizja TVN, https://dziendobry.tvn.pl/ (dostęp: 03.05.2020), https:// pl-pl.facebook.com/DzienDobryTVN/ (dostęp: 03.05.2020).

Forma, M. (2014). Historia gatunków medialnych (na przykładzie teleturnieju i magazynu śniadaniowego). W: R. Majzner, Obrazy przeszłości: Studia z zakresu historii, literatury i kultury. Częstochowa: Wydawnictwo Akademii im. Jana Długosza, 283-292.

Goban-Klas, T. (2009). Media i komunikowanie masowe. Teorie $i$ analizy prasy, radia, telewizji i Internetu. Warszawa: Wydawnictwo Naukowe PWN.

Hoghughi M. (2004). Parenting - an introduction. W: M. Hoghughi i N. Long (red.), Handbook of parenting. Theory and research for practice. London, Thousand Oaks, New Delhi: Sage Publications, 1-18.

Jankowska-Bulla, M. (2014). Telewizja śniadaniowa w Polsce i Niemczech: format - struktura - zawartość. Zeszyty Prasoznawcze. T. 57, 3(219), 536-564. DOI: 10.4467/2299-6362PZ.14.032.2366. www.ejournals.eu/Zeszyty-Prasoznawcze/ 


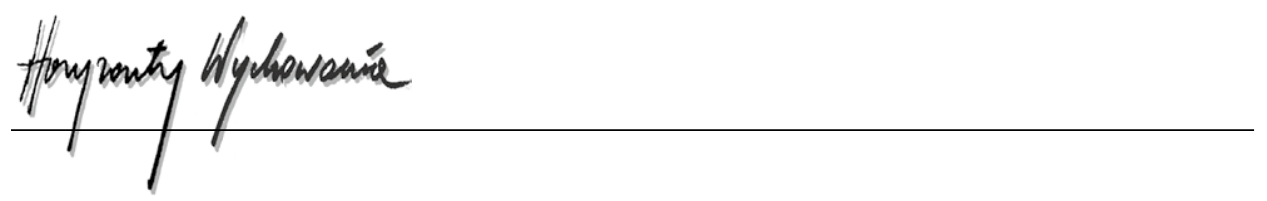

Kawula, S. (1997). Pedagogizacja rodziców. W: W. Pomykało (red.), Encyklopedia pedagogiczna. Warszawa: Fundacja Innowacja, 581-585.

Kwak, A. (2005). Rodzina w dobie przemian. Małżeństwo i kohabitacja. Warszawa: Wydawnictwo Akademickie „Żak”.

Marynowicz-Hetka, E. (2013). Pedagogizacja życia społecznego w optyce społeczno-pedagogicznej. Societas/Communitas, 2(16), 75-96

Pytanie na śniadanie (2019). TVP 2, https://pytanienasniadanie.tvp.pl/ (dostęp: 03.05.2020), https:// pl-pl.facebook.com/pytanienasniadanie/ (dostęp: 03.05.2020)

Rapley, T. (2010). Analiza konwersacji, dyskursu i dokumentów. Warszawa: Wydawnictwo Naukowe PWN.

Sanakiewicz, M. (2013). Poetyka telewizyjnych programów porannych: między informacją, tabloidem i autopromocją. Warszawa: Wydawnictwo Naukowe Scholar.

Sikorska, M. (2009a). Matka „chora” zamiast „złej” - o nowych wzorach macierzyństwa. W: M. Sikorska (red.), Być rodzicem we współczesnej Polsce. Nowe wzory w konfrontacji z rzeczywistością. Warszawa: Wydawnictwo Uniwersytetu Warszawskiego, 13-33.

Sikorska, M. (2009b). Nowa matka, nowy ojciec, nowe dziecko. O nowym układzie sił w polskich rodzinach. Warszawa: WAIP.

Skreczko, A. (2015). Parent Pedagogization as the Need of the United Europe. W: E. Osewska i J. Stala (red.), The Contemporary Family: Local and European Perspectives. Kraków: Wydawnictwo Uniwersytet Papieski im. Jana Pawła II w Krakowie, 285-296. DOI: 10.15633/9788374384414.18. http://bc.upjp2.edu.pl/dlibra/docmetadata?id=2854\&from=publication

Solarczyk-Szwec, H. (2010). W poszukiwaniu kategorii interpretacji uczenia się dorosłych. W: A. Fabiś i A. Stopińska-Pająk (red.), Uczący się dorosły w zmieniającym się świecie. Bielsko-Biała: Wyższa Szkoła Administracji, 35-45.

Stake, R. (2010). Jakościowe studium indywidualnych przypadków, tłum. M. Sałkowska. W: N.K. Denzin i Y.S. Lincoln (red.), Metody badań jakościowych. T. 1. Warszawa: Wydawnictwo Naukowe PWN, 623-654.

Śliwerski, B. (2003). Istota i przedmiot badań teorii wychowania. W: Z. Kwieciński i B. Śliwerski (red.), Pedagogika. Podręcznik akademicki. T. 2. Warszawa: PWN, 14-27.

Śniegulska, A. (2016). Edukacja do rodzicielstwa jako wyzwanie współczesności. Edukacja - Technika - Informatyka, 4/18, 96-101. DOI: 10.15584/eti.2016.4.11. https://repozytorium.ur.edu.pl/ bitstream/handle/item $/ 2323 / 11 \% 20 \%$ c5\%9bniegulska-edukacja. pdf?sequence=1\&isAllowed=y

Warzywoda-Kruszyńska, W. i Krzyszkowski, P. (2004). Przemiany składu rodziny oraz wzorców dzietności i wzorców zatrudnienia w Polsce na tle Unii Europejskiej. W: Z. Tyszka (red.), Współczesne rodziny polskie - ich stan i kierunki przemian. Poznań: Wydawnictwo Naukowe UAM, 59-70.

\section{Copyright and License}

This article is published under the terms of the Creative Commons Attribution - NoDerivs (CC BY- ND 4.0) License http://creativecommons.org/licenses/by-nd/4.0/ 